\title{
Cities and Gentrification in Contemporary Brazil
}

\author{
Rogerio Proenca Leite \\ Federal University of Sergipe, São Cristóvão, Brazil \\ Email: rproleite@gmail.com
}

Received 25 May 2015; accepted 15 August 2015; published 18 August 2015

Copyright (C) 2015 by author and Scientific Research Publishing Inc.

This work is licensed under the Creative Commons Attribution International License (CC BY). http://creativecommons.org/licenses/by/4.0/

c) (i) Open Access

\begin{abstract}
This article provides an analysis of heritage policies in Brazil, focusing in particular on the emergence of gentrification processes, which have transformed cultural heritage into a cultural commodity, adapting historic cities to the new market logic. The private sector's increasing involvement in heritage policy management has led to a complex alteration in the concept of heritage from a "symbolic asset" to a "cultural commodity". This process entails recognizing forms of interaction based on consumption and presumes forms of heritage conservation based on market demands. The aim here is to discuss the impacts of these processes on the shaping of public sociabilities and ideas in relation to the use of city spaces.
\end{abstract}

\section{Keywords}

\section{Gentrification, Consumption, Urban Spaces, Cultural Heritage, Cultural Commodity}

\section{Introduction}

The symbolic relevance of cultural heritage is seen to derive from a convergence of meanings on its shared social value. In fact, it is precisely on this point that controversies have emerged over the formulation of heritage policies. The attribution of a heritage value to a particular cultural asset by state agencies responsible for heritage conservation has always included a somewhat random dimension. The problem is less acute when the cultural asset in question is important only to a certain section of society or a particular community. Cultural assets representative of large groups or societies as a whole, by contrast, are always more complex since they inevitably refer to a diverse range of urban identities that are increasingly fragmented due to contemporary social complexity. This question remains central to any present-day analysis of cities and forms of cultural heritage: how do contemporary processes of cultural globalization affect local heritage policies?

Addressing this question and highlighting the complexity of attributing a heritage value to any particular cul- 
tural asset, Canclini underlines that "any scientific or pedagogical intervention concerning heritage is a meta language; it does not make things speak, rather it speaks of and about them" (Canclini, 1997: p. 202). Attributing meaning to heritage inevitably implicates a field of dispute. Selecting a particular cultural asset as heritage is a meta language that looks to say something through heritage. Likewise, gentrification processes should be taken as a meta language through which new agents from contemporary urban settings speak through the most diverse and significant forms of cultural heritage across the world.

The contemporary panorama of the world's large cities has altered considerably since Glass (1963) first used the term "gentrification" to designate the process of re-occupying old districts of central London, adapting them for a new urban elite. The proliferation of gentrification processes worldwide seems to have led to an immense "wave", to use Smith's (2006) expression, which transforms the local experience of urban policy into a global strategy of urban planning. Indeed there does seem to be an empirically observable increase in policies for valorizing gentrified areas in many cities. These areas are no longer limited to New York, Boston, Lyon, Barcelona or London: the proliferation of gentrification processes has reached-albeit in an altered state with distinct nuances - old historical districts of major cities in central and peripheral countries across the world, transforming rundown urban areas into elegant points of consumption for the middle and upper classes (Zukin, 1995; Smith, 2006).

Although many controversies still exist concerning the concept of gentrification itself ${ }^{1}$, one aspect seems to be a consensus: gentrified spaces almost always result from substantial alterations in uses and users, invariably implying excluding socio spatial demarcations. These modern frontiers, very often founded on consumer patterns, have a strong political resonance: in general they imply the creation of spatial niches for new urban lifestyles, very often premised on excessive public security, and frequently accompanied by far from discrete types of socioeconomic discrimination.

It is in the current context of economic deregulation and flexible accumulation that gentrification policies linked to cultural heritage have encountered their most elaborate form as urban policy. Contemporary "revitalization" projects placed the old historical centres back on the public policy agenda, transformed into the efforts of municipal administrations to revive local economic policies by revalorizing their traditional localities (Martín-Barbero, 2000).

Transformed into a cultural commodity, historical heritage becomes adapted to the new market logic, entering into partnerships with the private sector, which has invested in these areas as lucrative business opportunities. The growing participation of the private sector in heritage management involves the complex conceptual alteration of heritage from "symbolic asset" to "cultural commodity". The process implies the recognition of forms of interaction based on the consumption and presupposes, first of all, an operationalization of the forms of conservation based on the needs of the market.

In practice, this signifies electing assets with the potential to meet the expectations for a financial return on the substantial investments made by the private sector. Given this scenario, it is highly likely, therefore, that this choice pays less attention to the actual historical and architectural significance of the assets and more to the economic rationale of the investments. One of the more direct outcomes of this market-oriented urban intervention is a proliferation of services and products aimed at consumers: gentrification processes thus imply making these spaces more amenable to an urban elite, creating what Featherstone (1992) calls an "aestheticization of everyday life". More than just segregating space through the income restrictions placed on the consumption of these products and services, this "aestheticization" is also related to the lifestyles of an urban middle class, whose habits and aesthetic sensibilities seem to be increasingly marked by the search for public areas that offer leisure and security at the same time.

\section{Cities and Cultural Heritage in Brazil}

The trajectory of heritage policies in Brazil reveals a sharp turn towards consumption practices, indicating a shift in the conceptual axis from an initial idea of heritage as the nation to the conception of heritage as a city-commodity. This process results in changes to the value of the symbolic assets to be preserved, refashioning the

\footnotetext{
${ }^{1}$ By gentrification I refer to a specific kind of intervention that alters the urban landscape by accentuating or transforming architecture with a strong visual appeal, adapting the new landscape to the demands of the real estate market, security, planning and urban sanitation, focused on use or reappropriation by the middle and upper classes, and resulting in spaces with a high degree of segregationism due to sociospatial demarcations that encourage the fragmentation of space into different places (Leite, 2010, 2013 and 2013b). For other definitions along similar lines, see Butler (1997), Atkinson \& Bridge (2005), Hamnett (2000) and Rubino (2005).
} 
concept of heritage as a symbolic place of the nation into a more fluid conception that involves practices focused on the consumption of places (Arantes, 2000; Leite, 2007).

However, these properly national origins of conservation policy in Brazil do not differ substantially from most of the experiences of European countries, related to the creation and consolidation of a political and cultural image of the nation, and taking the State as its main sponsor and agent. The cultural assets that became included in Brazil's cultural heritage were initially selected on the basis of their perceived capacity to express - in a model form - a particular official history as a supposed synthesis of a memory of those traditions considered more legitimate and representative of a national identity. Brazilian heritage, as a place where the "ghosts of the past and the imperatives of the present" circulate (Certeau, 1996), itself became an agent that builds and invents traditions.

Although substantially rooted in the same European historical justifications for the myths of nation founding, the origin of Brazilian heritage policies was much more recent than the majority of European experiences. It was only at the start of the twentieth century that the Brazilian state first acted to recognize, valorize and protect the country's built heritage.

These heritage practices emerged as an initiative of the so-called New State in 1937 under Getúlio Vargas, where they assumed a prominent place in the formulation of an official conception of culture, focused in the construction of the idea of the nation. This process was contemporaneous to the Old Republic, a period that represented a troubled transition in Brazilian politics. Marked by the tensions of a new institutional and political configuration, and by an equally complex economic setting involving the implantation of a salaried workforce and the beginning of the country's industrialization, the period represented a geopolitical reordering of the country, as Furtado (1987) showed, with the gradual and definitive shift of the national economic axis from the sugar-producing northeast to the coffee-producing and agro industrial economy of the southeast.

In this context, the major landmark in terms of cultural policies and the elaboration of an "official conception of culture" was the creation of the National Historic and Artistic Heritage Service (Serviço do Patrimônio Histórico e Artístico Nacional: SPHAN) through Decree 25 of 30 November 1937 (National Historic and Artistic Heritage, 1976). Initially conceived under the strong influence of the modernist thought of the 1922 Modern Art Week, which not only inaugurated a new aesthetic discourse, but also disseminated a new way of thinking about Brazil and its culture (Rubino, 1992), SPHAN was, therefore, one of the principal initiatives in the New State's nationalist policy. This relationship between modernists and heritage policies in the 1930s, which comprises one of the key aspects in the historiography of the origins of SPHAN, is apparent at both an institutional and conceptual level.

This collaboration between SPHAN and modernists initially took place during the elaboration of a draft billfor the "National Artistic Heritage Service", a project ledby Mário de Andrade at the request of the Minister of Education and Public Health (MES). It was the latter, Gustavo Capanema, following modernist principles, who enabled modernist intellectuals to provide input to the cultural policies of the New State. This approximation, which would result in the effective participation of various modernist intellectuals in the work of the MES (Fonseca, 1997), went on to delineate the conceptual profile of an embryonic "national culture", culminating in an architectural conception that would symbolize a newly emergent Brazilian tradition.

The idea of heritage is developed as an expression of 'national character,' at once historical and universal. Against the profusion of juxtaposed styles of eclecticism, a style which represented the idea of modernization for the republicanism of the time, the modernists turned to the interior of Brazil, more precisely to the colonial towns of Minas Gerais (especially the town of Ouro Preto), whose Baroque architecture could express a 'legitimate' past, representative of a Brazilian cultural originality:

In Brazil, modernism enableda return to the past, to the intense celebration of all those forms of expression considered traditional. (...) At that moment, in terms of the construction of the nation, the Baroque became emblematic, perceived as the first typically Brazilian cultural manifestation, imbuing it with the aura of the origin of Brazilian culture (Santos, 1992: p. 26).

The conservation paradigm in Brazil only began to change in the 1970s with the practical impacts of the Venice Charter (1964) and Quito Meeting (1967) on urban planning policies in the country. These events led to debates on combining heritage conservation with urban planning strategies as a means to obtaining 'sustainable' solutions. In Brazil, IPHAN's inability to meet its agenda of heritage conservation and maintenance with federal government resources alone was largely responsible for an increased decentralization of preservation policies in Brazil. This in turn helped flexibilize the difficult task of attributing value to certain assets that might be impor- 
tant to states and municipalities, but not to IPHAN's generic conception of national memory and identity.

This redefinition of the criteria for valorizing cultural assets thus marked the beginning of a complex trajectory in which Brazilian cultural heritage became incorporated into urban policies and linked to regional development and boosting tourism. These transformations helped shift the conceptual focus of preservation from an all-encompassing idea of nation to the valorization of heritage as a resource for the development of historic cities, with a particular emphasis on cultural tourism.

Strictly speaking, the potential mistakes of a heritage policy oriented by a market approachare not linked to the combination of tourism and heritage per se. A policy that officially enshrines a cultural asset to the point of making it unvisitable is equally undesirable. The problem is that the commercial demands of the tourist industry and so-called entrepreneurial urbanism subvert the logic informing the selection of thoseassets to be preserved, foregrounding only those with the potential to generate good financial returns. This problem seems to occurin many tourist cities, including, for example, in the strong Mexican cultural tourist industry, whose management has to deal with the 'voracity' of trans national economic groups, as Mantecón (2006) highlights in her research. Through consumption, the policies that combine tourism and heritage reinforce precisely the more monumental aspects of these assets, alienating them from their local historic meanings, constructed through the everyday practices of those actually living in these areas. More than a mistaken solution, it is the reoccurrence of the same mistake. Or more precisely: a policy orientation that almost always neglects the involvement of the more direct users of the built heritage.

What changed, therefore, in Brazil' sheritage policies from the 1990s onward was not just the conservationist framework's turn to tourism, but also the logic guiding the involvement of the public and private sectors in these heritage policies. This altered above all the criteria for selecting and preserving cultural assets. The central theme of "strategic planning" - a possible euphemism for the term "gentrification" and a kind of neoconservative wave of urbanism - is precisely the transformation of culture into a market sector and the economy itself into a cultural issue. In this "market cultural ism", to use Arantes's (2000) term, urban policy is primarily directed towards "image-making", intended to assist the pursuit of economic profitability through "urban renewal" practices based around "city marketing".

It is also worth emphasizing that although the basic argument justifying contemporary cultural gentrification policies continues to revolve around the idea of tradition, the way in which this concept operates is changing, since it presumes a revival of the idea of national heritage, combined with a market approach that treats heritage as a cultural commodity. This commercial dimension implies that the rationale behind conservation is centred on the practices that can add value to cultural assets, in the sense of enabling the profitability of the investments made, adding to the potential revenue that the restored asset can generate. Speaking of heritage as a cultural commodity, therefore, means stressing its exchange value based on the broadening of the economic spectrum of its use values. The central problem of this approach is not the existence of an economic dimension of culture, but the reduction of cultural value to economic value, which could subsume the properly cultural nature of heritage, resulting in a kind of "fetishization" of culture.

\section{Consumption and Culture}

As Featherstone (1992) stresses, the consumer dimension typical of gentrification policies actualized the connections between the culture of consumption and the production of commodities in contemporary society:

This involves a dual focus: first, on the cultural dimension of the economy, the symbolization and use of material goods as "communicators" not just utilities; and second, on the economy of cultural goods, the market principles of supply, demand, capital accumulation, competition and monopolization which operate within the sphere of lifestyles, cultural goods and commodities (1995: p. 121).

At this point I wish to return to an earlier analysis (Leite, 2007, 2008) of cultural consumption in which I highlighted two dimensions of consumption present in this context of gentrification: the first refers to the properly economic dimension of exchange, relating to the appropriation of commodities and defined by the financial possibilities for accessing the products and services available on the market. The second dimension refers to the cultural meanings of the symbolic act of consumption, conceived as a social practice that differentiates tastes and lifestyles, and demarcates social relations, as Featherstone emphasizes:

While a "logic of capital" can be affirmed to derive from production, perhaps it is also possible to affirm a "logic of consumption", which points to the socially structured modes of using goods to demarcate social rela- 
tions (1995: p. 35).

This logic of consumption, applied to interactive practices in gentrified spaces, provides a means of understanding how public sociabilities linked to the theme of heritage are structurally marked by the sociospatialization of differences, which are also affirmed through distinct forms of consuming cultural assets. Arantes examines this debate on the market's role in cultural practices, emphasizing that "far from simply generating uniformity, the market stimulates the generation and circulation of all kinds of resources capable of producing meanings of place and difference" (Arantes, 2000: p. 64).

Cultural consumption should be understood, then, as a practice that goes beyond the instrumental rationality of the act of buying products and affirms the uses and processes involved in appropriating signs. Moreover, as Baudrillard (1981) pointed out, this logic of exchanging signs has the aim of producing singularities. Although the latter author exacerbates the meaning of consumption practices through his notion of a "exchange/sign value" (which very often results in a debateable negation of the real needs informing the use values of commodities in the act of exchange), he emphasizes the symbolic dimension of consumption, which allows the concept to be adapted beyond a purely economic mechanism. For Baudrillard, socially there exists a "vital urgency to have to produce oneself as a meaning in a system of exchanges and relations. Simultaneously to the production of goods, there is an urgent need to produce significations, meanings, of ensuring that the one-for-the-other exists before the one and the other exist for themselves" (Baudrillard, 1981: p. 74). This double perspective of being a commodity-object and a meaning-object was also analyzed by Bourdieu in his text "Economy of Symbolic Goods." market and cultural values, he argued, subsist in relative independence, "even in those cases where the economic sanction reaffirms cultural consecration" (Bourdieu, 1999: p. 103). What Baudrillard and Bourdieu both seek to emphasize, each in his own way, is simultaneously the symbolic nature of the exchanges and the economic dimension of culture.

Ways of dressing, eating, travelling through the urban landscape, occupying particular spaces and transforming them into places (albeit ephemeral) in which individuals recognize each other and affirm their differences, all represent symbolic forms of consuming and demarcating specific forms of belonging. For this reason, and considering cultural consumption as "the set of processes for appropriating and using products in which symbolic value prevails over use and exchange values, where at least the latter become subordinate to the symbolic dimension" (Canclini, 1993: p. 34), the different meanings attributed to places and the form in which they are appropriated (consumed), delineate the tensions and disputes surrounding the uses and meanings attributed to urban spaces as public spaces.

Consequently, and mindful that "to consume is also, therefore, to exchange meanings" (Canclini, 1993: p. 29), while the economic dimension of consumption (related to needs) can set limits to inter activity in the context of gentrification practices, cultural consumption (related to the wider meanings of the uses), rather than contributing to the emptying of public space, may indicate the complex and ambivalent persistence of a political dissension of places, which feeds on the different uses and consumptions of places. This cultural ambiguity of heritage, conceived through the notion of use, connects the topic to the challenges of building a political identity within a society that projects itself as plural. Moving beyond an official viewpoint that presumes to know the meanings of the assets to be officially listed, it is possible, therefore, to comprehend heritage instead through the meanings attributed to it, as Durham (1984) underlines:

From this viewpoint, we should attempt to define heritage according to the meaning that it holds for the population, recognizing that the basic element in the perception of the meaning of a cultural asset resides in its use by society (Durham, 1984: p. 30).

In Durham's conception, therefore, the process of attributing value to cultural as sets retains an essentially political dimension. The use - or the "sign value" to employ Baud rillard's terminology — made of a cultural asset in a consumer society may frequently conflict with its attributed economic value, since every evaluative dimension necessarily involves choices, forms and perspectives of seeing and relating to a cultural asset. Two modalities of cultural values defined by Menezes (2000) help to clarify the nature of the use values of cultural assets spoken of by Durham, Arantes and Canclini.

Menezes refers to the "affective value" and the "pragmatic value" of cultural assets. The former relates "to the subjective relations of individuals (in society) with spaces, structures, objects [...] that feed the processes of identity or social memory" (Menezes, 2000: p. 38). "Pragmatic value" can, in turn, can be understood as "the use values perceived as qualities" (Menezes, 2000: p. 38). A concept of use that recovers the meanings attributed by society to cultural assets needs to combine the "effective value", determined by the sense of "belonging" 
of individuals, and the "pragmatic value", which implies the qualified use of assets without reducing them to any single specific use. Ignoring this extended concept of use may reduce the evaluative spectrum of a cultural asset, becoming no more than an exchange able commodity determined by a specific need.

As a symbol, the exchange value of a cultural asset increases in direct proportion to the diversification in its use values, as defined by different agents. On this point Appadurai (1986) highlights the asymmetric nature of the cultural value of commodities. Symbolic exchanges involving cultural commodities do not always exhibit an equivalence of values and meanings between the parties as economic exchanges presume. The "regimes of value" as the author defines them, depend on the specificities of the contextual and cultural meanings involved in the exchange:

"The variety of such contexts [of symbolic exchange] within and across societies provides the link between the social environment of the commodity and its temporal and symbolic state" (Appadurai, 1986: p. 15).

Gentrification practices are distinguished, therefore, from other traditional forms of attributing value and conserving heritage since they employ a wider form of selecting assets, based on criteria that extend beyond an evaluative conception of the nation. However, preservation policies founded on the debatable idea of a national (or local) memory, or guided by a no less questionable consumer logic, are equally selective forms of symbolic intervention and appropriation, constructed on the basis of particular social conceptions: one presumes the effectiveness of a shared memory for convergent actions within a nation (or within a particular locality), while the other channels the potential value of consumer actions within the cultural market.

\section{The Bairro do Recife Experience}

In Brazil, one of the most remarkable instances of gentrification took place in the historic Bairro do Recife district of the capital of Pernambuco state, a process begun in the 1990s. This district comprised the original heart of the city, where Recife's first instance of urban planning was introduced, inspired by the Dutch expansion plan of Maurício de Nassau, with the engineer Peter Post (Freyre, 1996). For years, the district's port was one of the most important of the Americas, especially at the height of sugar production (Bernardes 1996, Perruci 1978). With its townhouses and narrow streets, the district was subject to a major reform at the beginning of the twentieth century, following the example of Rio de Janeiro's sanitary reforms that adhered to the principles of Haussmann's designs for Paris (Lubambo, 1991; Leite, 2007). Renovated in the urban style of nineteenth century Paris, with its eclectically styled buildings, the district underwent a proto gentrification phase (Smith, 1996) and become one of the city's most sophisticated spaces, a symbol of a late modernity sought in Brazil.

From the post-war period to the mid-1980s, the district suffered the same population decline that affected most of Brazil's major port cities. Following the loss of its housing role, the district became an inhospitable space, a favoured area for prostitution and a decadent bohemia. In the 1990s, a comprehensive gentrification of the district began, with the recuperation of part of its built heritage and its transformation into an extensive space of leisure and consumption for the middle and upper classes. The district became one of the city's most disputed centralized locations and the focus of diverse sociabilities (Leite, 2007).

A similar process occurred with the "revitalization" of the Pelourinho in Salvador, Bahia. The "Pelourinho Operation", as it became known, was an ambitious project to restore one of the most impressive architectural complexes of Brazil's colonial period, and became a precursor to gentrification practices across the country. Situated in the historic centre of the city of Salvador, the capital of Bahia state, the Pelourinho underwent a "lightning" reform when, in 1992, the state government invited bids for private companies to undertake the reform in a period of 150 days to conclude the work (Fernandes, 1995). Eventually taking three years to complete, the reform was heavily criticized for various aspects, beginning with the fact that it had been carried out virtually without the knowledge of the municipal and federal conservation bodies: "In open conflict with the Salvador Municipal Council, almost none of the works implemented in the Pelourinho had authorization from the municipal bodies. Likewise, few of the building recuperation projects had received approval from the then IBPC, today IPHAN, most of them being turned down" (Fernandes, 1995: p. 47).

The short deadlines and the involvement of companies for the most part unqualified to carry out restoration work meant that the intervention also came under severe criticism in architectural terms. The City Colours Project (Projeto Cores da Cidade) was responsible for most of the façade painting, imprinting the same scenographic style found into day's 'revitalization' policies. Although based on a strongly state-centred management model, the Pelourinhoreformation can be seen as a forerunner to gentrification policies for three motives: 1) the 
complete absence of a policy taking into account the users already living in the area, where restrictions on residential use led to the expulsion of many of the area's traditional occupants (Fernandes, 1995: p. 48); 2) the idea of creating an open air shopping centre by providing incentives for commercial exploration of the new space (Fernandes, 1995: p. 50); 3) the fact that heritage was treated mainly as simply a cultural commodity, not a symbolic asset for the population. The Pelourinho, constructed as a landscape of power, also resulted in a "picture postcard and tourist com modification of Salvador" (Pinho, 1997).

The gentrification phase of Bairro do Recife and the Pelourinho in Salvador coincided with the development of a new conservation model for Brazil's historical heritage, the main guidelines of which can be identified in a symptomatic phrase of the then Minister of Culture, Francisco Weffot: "Cultural Heritage in Brazil is not just a question of culture, it is also an economic issue."

This relation between heritage and economics is not something new in conservation policies. In an article on Paris, Certeau (1996) emphasized that the policies for renovating rundown districts can be traced back to the Malraux Law (1962), whose heritage restoration strategies were based on a kind of aesthetic intervention guided by a market logic involving the reactivation of commerce and real estate appreciation ${ }^{3}$.

The latter has been one of the most heavily discussed aspects of gentrification, especially in relation to the residential dimension of these enterprises. The belief is that, without this characteristic, these projects would lack one of the primary bases for generating routine service essential to everyday life. However, the Recife and Salvador cases repeat a tendency that has become almost standard in Brazil: namely, the failure to incorporate housing policies in "revitalization" projects, neither in the form of improving the living conditions of the poorer populations usually living in these central areas of cities (mostly port regions), nor in the form of new housing developments.

Sticking with just the better known examples, we can highlight a number of other gentrification processes in Brazil that lacked this residential dimension: Estação das Docas (Belém, Pará), Pelourinho (Salvador, Bahia), Praia de Iracema (Fortaleza, Ceará), Mercado Central (Aracaju, Sergipe), the Historic Centre of João Pessoa (Paraíba), Praça XV and the surrounding area (Rio de Janeiro) and the Luz region (São Paulo). In practically all these cases, the absence of a residential component has made the gentrification processes in Brazil predominantly touristic in inclination, not only in terms of the type of investment made, such as the adaptation of urban infrastructures for visitors, but also in terms of the target public for these spaces. Perhaps this is why we mostly encounter an ostensive and radical transformation in the uses of these spaces, adapting them to meet the immediate demands of consumption and entertainment.

It is difficult to assess the degree of vulnerability of these interventions on this point since the main agents involved are traders and consumers, rather than residents. However, we lack empirical cases to develop this comparative perspective since there are no really typical cases of residential gentrification in Brazil. Some of the historic centres with a strongly residential dimension currently being 'revitalized' in the country have few of the characteristics attributed to gentrification processes, as illustrated by the cases of São Luís (Maranhão), Olinda (Pernambuco) and Ouro Preto (Minas Gerais), to cite only the examples of world heritage cities. In general, these cities not only are densely populated, but also possess an everyday life identical to any other average Brazilian city. This means that they would be unable to support gentrification for the simple reason that they lack areas abandoned enough to allow a radical alteration in their uses and the substitution of users.

On the other hand, despite the specificities of markedly residential cases of gentrification in old European cities, we know that gentrification practices acquire other configurations, along with a relative degree of stability and continuity, when these enterprises include maintaining their old residents or introducing robust policies for attracting new residents, as shown by the cases of the Portuguese city of Évora, the Saint-Gilles district of Brussels, the Saint-Georges district of old Lyon, and La Ribera in the historic part of Barcelona.

The absence of this residential dimension in Brazilian cities with gentrification processes is highly ambiguous. On one hand, the revitalization plans emphasize the importance of attracting residents and developing housing policies, including for the low-income population potentially living in these areas. On the other, though, these policies rarely make any real investment in providing improvements for the older residents of these historic centres, which, very often due to the deteriorated state in which they are found, are inhabited precisely by people

${ }^{2}$ Weffort, Francisco. "Artigos selecionados”. Brazilian Ministry of Culture website, March 1999.

${ }^{3}$ The Malraux Law, alluding to André Malraux, then French Minister of Education and Culture, represented an important state initiative to preserve rundown districts (Malraux Law, 1980). As Perrin (1980) emphasizes, the Malraux Law inaugurated a new policy for preserving France's heritage, introducing a policy of tax breaks for owners who carried out restoration, anticipating a practice that would become widespread at the end of the 1990s in gentrification policies (Perrin, 1980). 
with low incomes.

\section{Heritage, Market and Consumption}

Another prevalent idea concerning gentrification policies is the economic self-sustainability of cultural heritage. This notion is not necessarily contradictory. Much the opposite: it seems reasonable to suppose, at first sight, that certain heritage assets can, once rationally explored, provide for their own upkeep - an area that typically comprises a substantial drain on public finances. I do not believe that this is the real issue. Perhaps the problem can actually be traced to how uses of heritage are designed on the basis of economic prospects.

Private sector involvement in the management of heritage policies entails a complex alteration in the very definition of heritage from "symbolic asset" to "cultural commodity". The process implies forms of interaction based on consumption and, first and foremost, presupposes that conservation strategies are implemented in accordance with market needs. In practice this signifies a selection of assets with the potential to meet expectations for financial returns on the high level of private sector investments.

To ground this discussion on empirical data, I turn to the case of the old Igreja do Pilar (Pilar Church) in the Rato Favela of the historic district of Recife, the Bairro do Recife Antigo. Listed by IPHAN, the church dates from 1680, making it one of the oldest in the city, and is today in a state of total abandonment and complete deterioration, despite the highly publicized revitalization of part of the district concerned.

The Rato Favela, or Our Lady of Pilar Community, started to be built in 1975 on landdisappropriated by Portobrás, precisely in the area surrounding the Pilar Church (Igreja Nossa Senhora do Pilar). Even before the port reform in $1910^{4}$, though, this area was a place of intense everyday life. Likewise the church remained an important landmark in the social memory of the favela's residents, as revealed by Francisca Lopes Gomes, one of the oldest residents, who witnessed the various "revitalization" phases of the Bairro do Recife first-hand:

The church here in Pilar, today abandoned, held mass every Sunday, a procession in May, a procession, it was all here. (...) On Sundays I'd go to the mass here in the Pilar Church ${ }^{5}$.

The Bairro de Recife Revitalization Plan ${ }^{6}$ directly mentioned the possibility of changing how this area was used, including plans for the Pilar Trade Centre, a kind of support complex for the port activities, which would require the removal of residents from the favela to other housing units in the district, including the Renovation Sector itself, through the construction of mixed low-income housing and commercial units ${ }^{7}$. For the Bairro do Recife area, located within the Renovation Sector, the Plan anticipated urban uses connected to wholesale and retail trade, traditional services, industry and housing 8 .

The Plan's idea for housing was focused not on the old residents but on potential newcomers with a different socioeconomic profile. In fact, a change of focus had taken place, perceptible on a closer reading of the two existing versions of the same Plan. The first version directly mentioned Pilar's residents and the potential benefits to them of building low-income housing. The second version, however, excised any reference to these residents. The Pilar Trade Centre became seen instead as a "new front of productive investments in the district", serving as an "example, for private capital, of the profitability of reconverting the stock of historical buildings". What had been low-income housing was transformed into "marketable units" 10 to be implanted when "the problem of the relocation of the Rato Favela is resolved by a specific project" $"$.

The Pilar Church, set in the middle of the favela, appears emblematic of the impasses faced by the economic self-sustainability of heritage, for two reasons. First, the obvious fact of being a church, which limited the possibilities for altering its original use. Apart from the creation of a Museum open to visitors or something similar, it would be difficult to find another suitable function for the building. Second, its location in the middle of a favela would make the social and political cost of removing its residents against their will practically infeasible without

${ }^{4}$ I refer to the urban and architectural reform of the district, which transformed it into a Brazilian example of Haussmann's Paris (see Leite, 2007).

${ }^{5}$ estimony of Francisca Lopes Gomes. Interviewed by the author, 11 April 2000, in Bairro do Recife.

${ }^{6}$ Pernambuco State Economic Development Agency (AD/DIPER). Plano de Revitalização-Bairro do Recife. PlanejamentoUrbano e Economia vol. 1. Recife, 1992.

${ }^{7}$ Ibid: 62 .

${ }^{8}$ Ibid: 52.

${ }^{9}$ Zanchetti et al. (1998), Revitalização do Bairro do Recife: Plano, Regulação e Avaliação.Centro de ConservaçãoIntegrada Urbana e Territorial, Master's Course in Urban and Regional Development, UFPE, p. 48.

${ }^{10}$ Ibid: 47.

${ }^{11}$ Ibid: 48 . 
actions designed to improve the locality. Very often unable to change how they are used, the favela and the church end up receiving no concrete forms of intervention, since they lack what the experts call the "economic viability" of any enterprise.

Now, if the only criteria informing investments in the recuperation and preservation of heritage is economic sustainability, cases like the Pilar Church would probably be insurmountable, unless the high social cost of these very often unpopular and segregationist measures is taken on, given that ultimately they seem to want the "relocation" of these residents, in a latter-day version of the sanitation policies that marked the Haussmann-style reforms in Brazil and elsewhere.

Here we encounter a dilemma, which could be described as follows: when a particular cultural asset can be converted to new uses, it contains a strong marketing potential and, therefore, becomes the preferential target for heritage policies based on the pursuit of economic self-sustainability. When the opposite is the case, though, the asset loses its profit potential and is dropped from the agenda of funding programs and agencies. Although the fundamental argument justifying contemporary cultural policies remains centred on the idea of tradition, the way in which this concept is used has changed, since it presumes a revival of the idea of national heritage, combined with a market-based conception that treats this heritage as a cultural commodity. This commercial dimension implies that the reasoning behind conservation is focused on practices that can add value to cultural assets, in the sense of enabling a return profit on investments, combined with the potential revenue from the restored asset.

It is no doubt unnecessary to recall the strong political impact that such ideas have on the social memory of some sectors of the population, historically forgotten and marginalized by heritage policies. As I highlighted earlier, therefore, it seems to be the sad fate of these cultural minorities to leave the patronage of the State only to fall under the sway of the market: while the State pushed them to the margins of heritage policies because these predominantly focused on buildings that could represent the official symbols of an idea of a white Catholic nation, the market, eager for a return on each dollar invested, has no interest even in these dominant symbols if they fail to present possibilities for a return on investments.

\section{The Spectacularization and Detraditionalization of Culture}

Certainly many truisms can be found in the current debate on cultural heritage. One of them is the well-known correlation between heritage and identity, the basis for analyses that foreground - correctly in most cases - the role of heritage, in all its different acceptations and formats, in building and maintaining certain local and traditional pillars of ontological security. I am sure nobody doubts the strong effect that the appeal to shared heritage can have on maintaining a sense of community, especially at a time when modern urban identities are becoming increasingly pulverized.

However, despite the apparently self-evident nature of the topic, there is one aspect that can and should be discussed still, running counter to the clearly predominant tendency to find positive correlations among the terms. I refer to a process - in some cases equally desirable — of detraditionalizing heritage, and the consequent loss of stable reference points for social identity. In other words, I would argue that in certain contexts of gentrification and extensive heritage consumption, a relative degree of detraditionalization may be preferable to the reinforcement of the cultural meanings that sustain the connections needed to form certain urban identities. This argument is centred on the idea that gentrification policies, in order to make cultural heritage widely consumable, require a double and apparently paradoxical movement: intervention policies need to promote more flexible local cultural meanings in order to make them accessible to global consumer patterns and, at the same time, they need to restore certain aspects of the local culture in order to encourage recognition of local specificities (necessary to reactivating consumption practices) through a retraditionalization of culture.

Another characteristic, however, seems to inevitably accompany gentrification processes, especially those in heritage areas, namely, the change in uses and users typically involves making certain local cultural traits more flexible. As I have suggested here, this flexibilization to a certain extent incurs a detraditionalization of heritage, shifting more traditional aspects of local culture to the consumer sphere, typical of non-residential gentrification. This process is very common in Brazilian cities that have undergone these kinds of interventions, including Belém, Salvador, Recife and Fortaleza. As the French researcher Bidou-Zachariasen (2006) suggests, this can be called "visitor gentrification". These can therefore be seen as typical cases in which the changes in uses and users primarily occur at tourist level. This kind of gentrification is particularly suited to the observation of contemporary processes of transforming heritage into commodities, given their strong focus on drawing in visitors 
as a form of ensuring the necessary returns on investments. Consequently, it is precisely these types of gentrification that afford us the clearest view of the processes of detraditionalization and retraditionalization.

The former process, which refers to the flexibilization of local cultural meanings, is readily observed in the attempts to make these spaces accessible to a variety of people. It is not just accessible, but appropriable from symbolic and cultural viewpoints. The adjustments that flexibilize tradition are not merely formal processes, although they openly advertise themselves as urban marketing strategies. Very often they involve rearrangements of the everyday that modify how users interact within these spaces. This flexibilization also has a double function: first, to promote the inclusion of these heritage spaces in the global flow of symbolic consumption; second, to reactivate, in the opposite direction, the retraditionalization needed to legitimize the urban gentrification processes both culturally and politically.

Cultural flexibilization also tends to activate a retraditionalization of spaces and, concomitantly, reinforce local cultural meanings. This process, which I was able to observe previously in my study of the Bairro do Recife (Leite, 2010, 2013b), involves stimulating manifestations of local popular culture as a way to activate certain parameters of cultural legitimacy of these spaces. However, these manifestations frequently have no real connection to the local area, though they are presented as typical in order to create these potential sources of identity. The problem is that they are really no more than a retraditionalized "spetacularization" with the objective not of forging cultural identities, as such, but of appealing to consumers. Ultimately, the aim is to attract new users, focusing on the possibilities for consuming the space, whether in the form of access to bars and restaurants, or in the form of the symbolic consumption of these artistic-cultural manifestations.

These two movements of deterriorializing and reterritorializing cultural heritage in contexts of gentrification also have some impacts on everyday forms of structuring identities. Traditionally associated with national expressions of identity, the heritage-commodity in gentrified contexts loses its previous symbolic capacity to materialize the abstract sense of belonging to a nation (Arantes, 1997). The anti-identificatory nature, so to speak, of this heritage-commodity is revealed precisely by the mechanisms used to flexibilize local cultural aspects and to allow this heritage to be consumed by anyone, irrespective of the actual cultural connections.

In saying this, I do not mean to imply that no identity-forming processes occur in gentrified spaces. As I was able to explore in earlier works (Leite, 2008, 2010), gentrification processes are not incompatible with the formation of identity places, which continue to exist by means of a complex socio spatial demarcation that acquires meaning through the structuring of public spaces. On this point, it is worth recalling that identities are not pregiven but elaborated on an everyday basis in the course of political interactions.

As for the discussion of the existence of what I called "counter-uses", I have looked to show how the existence of certain places in gentrified spaces contributes precisely to reaffirming certain delimitations that are constitutive of identities. Hence, this delimitation of places is relational, in just the same way as the identity-forming processes: it exists due to the need for a differentiation that makes place a spatially and socially recognizable singularity. This contrastive and differential aspect implies the existence of representations that may be-and generally are - antagonistic: what makes a space a place for some may be precisely what for others enables the contrastive construction of their own places. It is in this sense that a place is always a singular space for the construction of difference: in it are inscribed the marks that characterize the different demands of belonging to a collectivity (Leite, 2013).

The same applies to the notion of identity. As a differentiating process, identities are also structured through contrastive and conflictive mechanisms. Gentrification policies operate a certain reduction of these conflicts by levelling the possibilities for recognition through consumption practices and the transformation of heritage into a mere cultural commodity.

By hindering the formation of places, gentrified spaces attempt to depoliticize social practices insofar as they reject singularities. Likewise, they turn urban spaces into smooth areas, without conflicts, spaces or identities, and make everyone "equal" at the level of the being-value, in the mere life of the Transparency Society (Han, 2014).

\section{References}

Appadurai, A. (1986). The Social Life of Things: Commodities in Cultural Perspective. Cambridge: University Press. http://dx.doi.org/10.1017/cbo9780511819582

Arantes, A. A. (2000). Paisagens Paulistanas: Transformações do espaçopúblico. Campinas: Ed.Unicamp. 
Arantes, O. (2000). Estratégia fatal. In C. V. Arantes, \& E. Mericato (Eds.), A cidade do pensamentoúnico (pp. 5-16). Petrópolis: Vozes.

Atkinson, R., \& Bridge, G. (Eds.) (2005). Gentrification in a Global Context: The New Urban Colonialism. London: Routledge. http://dx.doi.org/10.4324/9780203392089

Baudrillard, J. (1981). Para umacrítica da economiapolítica do signo (p. 70). Lisboa: Edições.

Bidou-Zachariasen, C. (2006). De volta à cidade: Dos processos de gentrificaçãoàspolíticas de "revitalização" dos centrosurbanos. São Paulo: Anablume.

Bourdieu, P. (1999). Practical Reason: On the Theory of Action. Stanford, CA: Stanford University Press.

Butler, T. (1997). Gentrification and the Middle Classes. Aldershot: Ashgate.

Canclini, N. G. (1993). El Consumo Cultural en México. México: Consejo Nacionalpara la Cultura y las Artes.

Canclini, N. G. (1997) Culturas Hibridas. São Paulo: Edusp.

Certeau, M. (1996). Ainvenção do Cotidiano: Artes de fazer. Petrópolis: Vozes.

Durham, E. (1984). Movimentos Sociais: A construção da cidadania. Novos Estudos, CEBRAP, No. 10, 24-30.

Featherstone, M. (1992). Consumer Culture and Postmodernism. Londres: Sage Publications.

Fernandes, A., \& Gomes, M. A. A. F. (1995). Operação Pelourinho: O que há de novo, além das cores? In S. Zanchetti, G. Marinho, \& V. Millet (Eds.), Estratégias de intervenção em Áreas Históricas: Revalorização de areas urbanas centrais (pp. 46-52). Recife: Mestradoem Desenvolvimento Urbano-UFPE.

Fonseca, M. C. L. (1997). O Patrimônio em Processo: Trajetória da política federal de preservação no Brasil. Rio de Janeiro: Editora UFRJ/MinC-IPHAN.

Freyre, G. (1996). Sobrados e Mucambos. São Paulo: Record.

Glass, R. (1963). Introduction to London: Aspects of Change. London: Centre for Urban Studies.

Hamnett, C. (2000). Gentrification, Postindustrialism, and Industrial Restructuring in Global Cities. In G. Bridge, \& S. Watson (Eds.), A Companion to the City (pp. 331-341). Oxford: Blackwell Publishing.

Han, B.-C. (2014). A Sociedade da Transparência. Lisbon: Relógio D’Agua.

Leite, R. P. (2007). Contra-usos da Cidade: Lugares e espaço público na experiência urbana contemporânea (2ºdição). Aracaju: Editora UFS/Campinas, Editora da UNICAMP.

Leite, R. P. (2008). Localizando o espaço público: Gentrification e cultura urbana. Revista Crítica de Ciências Sociais, No. 83, 35-54. http://dx.doi.org/10.4000/rccs.436

Leite, R. P. (2010). A exaustão das cidades: Antienobrecimento e intervenções urbanas em cidades brasileiras e portuguesas. Revista Brasileira de Ciências Sociais, 25, 73-88. http://dx.doi.org/10.1590/S0102-69092010000100006

Leite, R. P. (2013). Argomentazioni critiche per non dimenticare: Pratiche del quotidiano e contro-usi della città. In M. Ricci, C. M. R. Gagliardi, \& D. M. T. Baptista (a cura di) (Eds.), Recupero dei centri storici: Brasile e Italia, esperienze a confronto (pp. 141-156). Rome: Gangemi Editore.

Leite, R. P. (2013b). Consuming Heritage: Counter-Uses of the City and Gentrification. Vibrant: Virtual Brazilian Anthropology, 10, 165-189.

Lubambo, C. W. (1991). O Bairro do Recife: Entre o corposanto e o marco zero. Recife: CEPE/Fundação de Cultura Cidade do Recife.

Mantecón, A. R. (2006). Turismo cultural en México: ¿un modelo alternativo? Caderno CRH, 19, 499-506.

Martín-Barbero, J. (2000). Dislocaciones del tiempo y nuevas topografias de la memoria. In H. B. Hollanda, \& B. Resende (Eds.), Artelatina: Cultura, globalização e identida des contemporâneas (pp. 57-72). Rio de Janeiro: Aeroplano Editora.

Menezes, U. T. B. D. (2000). Valor Cultural, Valor Econômico: Encontros e desencontros. Seminário Internacional História e Energia. São Paulo: Fundação Patrimônio Histórico de Energia de São Paulo.

Perrin, J.-B. (1980). O exemplo francês de proteção, do remanejamento e da valorização do patrimônio histórico urbano. In Pró-memória-Spahn-MEC, Restauração e revitalização de núcleos históricos: Análise face à experiência francesa. Brasília: IPHAN.

Pinho, O. S. D. A. (1997). Descentrando o Pelô: Narrativas, territórios e desigualdades raciais no centro histórico de Salvador. Dissertação de Mestradoem Antropologia, Campinas: UNICAMP.

Rubino, S. (1992). As Fachadas da História: Os antecedentes, a criação e ostrabalhos do Serviço do Patrimônio Histórico e Artístico Nacional, 1937-1968. Dissertação de Mestradoem Antropologia, Campinas: IFCH-UNICAMP.

Rubino, S. (2005). A Curious Blend? City Revitalization, Gentrification and Commodification in Brazil. In R. Atkinson, \& G. 
Bridge (Eds.), Gentrification in a Global Context: The New Urban Colonialism (pp. 225-240). London: Routledge. http://dx.doi.org/10.4324/9780203392089 chapter_14

Santos, M. V. M. (1992). O Tecido do Tempo: a Idéia de patrimônio cultural no Brasil 1920-1970. Tese de Doutoradoem Antropologia, Brasília: Universidade de Brasília.

Smith, N. (1996). The New Urban Frontier: Gentrification and Revanchist City. London and New York: Routledge.

Smith, N. (2006). A gentrificação generalizada: De uma anomalia local à "regeneração" urbana como estratégia urbana global. In: C. Bidou-Zachariasen (Eds.), De volta à cidade: Dos processos de gentrificação às políticas de "revitalização" dos centros urbanos (pp. 25-39). São Paulo: Anablume.

Zukin, S. (1995). The Cultures of Cities. Cambridge, MA: Blackwell. 